\title{
Practical, rapid, and cost-efficient interior architectural precautions for prevention of COVID-19 in the workplace
}

\author{
Gurkan Ozenen \\ Department of Architecture, Faculty of Fine Arts and Design, Dogus University, Acibadem, Istanbul, Turkey
}

Received 4 June 2020

Accepted 11 July 2020

\begin{abstract}
.
BACKGROUND: During the COVID-19 pandemic, it has been essential for some workplaces to stay open. Considering the rapid spread of the virus, interior architectural re-designing of these essential workplaces such as markets, banks, and drugstores is crucial for prevention. The employees, as well as the customers in these workplaces, have a high infection rate. Some precautions need to be taken urgently to prevent the spread of the disease. Some workplaces may have already performed their action plan whereas others have not.

OBJECTIVE: Some practical, rapid, and cost-efficient preventive precautions are presented in this paper for employers to take action in their workplaces.

METHODS: Two new proposals are advised to be carried out. The contents of these newly designed barriers will be introduced.

RESULTS: Some practical and cost-efficient ideas are given within this report.

CONCLUSION: All the preventions proposed in this paper are claimed to reduce the spread of COVID-19 and may save lives around the country as well as the world.
\end{abstract}

Keywords: COVID-19, pandemic, workplaces, prevention

\section{Introduction}

The onset of COVID-19 [1] has brought changes to the way in which people around the world interact with each other both indoors and outdoors. When it comes to the inside of a space, not so long ago, architects specializing in interior design needed time to create logical designs, which would satisfy the client's requirements. Now, with the current pandemic, interior architects face the challenge of

*Address for correspondence: Gurkan Ozenen, Arch, PhD, Department of Architecture, Faculty of Fine Arts and Design, Dogus University, Acibadem, 3722, Istanbul, Turkey. Tel.: +90 44479 97; E-mail: gozenen@yahoo.com. changing existing spaces in a fast, practical and costeffective manner.

The Swiss architect Le Corbusier described tabula rasa as a blank canvas in which architects would freely create a novel concept from nada. The design, within this notion, has a specific place, which could be singular or pluralistic in nature, and therefore will be a key component of the architectural and site relationship [2]. With the current COVID-19 pandemic, the idea of tabula rasa became impractical. Therefore, the current challenge is to create designs that would not require to start from zero, but rather use what already exists (to help prevent the spread of COVID-19). 
Table 1

Illustrations of the approximate lifespan of COVID-19 on some surfaces [3]

\begin{tabular}{|c|c|}
\hline Surface & COVID-19 approximate lifespan \\
\hline Paper tissues and paper & 3 hours \\
\hline Copper (coins) & 4 hours \\
\hline Cardboard & 1 day \\
\hline Wood & 2 days \\
\hline Cloth & 2 days \\
\hline Stainless steel & 2-3 days \\
\hline Polypropylene plastic & 3 days \\
\hline Glass & 4 days \\
\hline Money bills (paper) & 4 days \\
\hline Outside of masks & 7 days \\
\hline
\end{tabular}

A recent study reported that approximately $10 \%$ of the workforce in the United States are in occupations in which infection exposure could occur once a week [3]. Given the nature of COVID-19, this number becomes hard to estimate due to the speed in which it spreads.

Although several countries took extraordinary steps to impose some form of lockdown, shelter-inplace or quarantine, there were still some businesses that were deemed essential and remained open during that phase of the pandemic. Both employees and customers in these essential businesses could be susceptible to viral infection due to the proximity needed to conduct transactions. For instance, a female employee, say at your local supermarket, could acquire the virus from an infected customer when accepting money at the register, and then accidently touching her eyes with her, now, contaminated hand; or even if the infected customer accidentally sneezed on her. Some literature suggested that COVID-19 was found to be suspended in the air, and also it can be transmitted via coughing and sneezing [1]. Although personal protective equipment (PPE) such as face masks, gowns or gloves can provide some level of protection to employees, they could still face the risk of contamination since COVID-19 may survive on surfaces such as metal, clothes and cardboards (Table 1). Another report suggested that COVID-19 
could be present for up to seven days on the outwardfacing side of a surgical mask [4].

The aim of this article is to suggest some practical, rapid and cost-effective changes to workspaces that could potentially reduce transmission of the virus. In addition, it will discuss how different plastic barrier designs can protect both employees and customers. And finally, how to improve money exchange methods, with the aim of decreasing potential sources of infection. In short, this article will mainly focus on effective ways in which minor changes in interior design can help decrease the spread of COVID-19.

\section{Methods}

In most countries, a business transaction involves exchanging some type of currency between a customer and an employees on the other side of the counter (for instance, the cashier of your local favorite ice cream parlor taking your $\$ 10.00$ bill and giving your $\$ 3.75$ change back for a decadent two scoops of iced cream). Given the example, an employee could be either a COVID-19 carrier or become infected from a customer. Therefore, it is paramount to reduce the interaction between these individuals as much as possible.

In the next sections, this article will discuss some practical and fast changes that can be implemented in order to prevent the transmission of COVID-19. Also, two different types of new barrier designs will be introduced.

\subsection{Monitoring the temperature}

It is crucial to regularly monitor body temperatures of all team members. A digital touchless thermometer is the ideal tool for such a task. It is recommended that an individual should be in charge of taking temperatures at the entrance of the facility [5]. As background, someone with temperature readings above $37.7^{\circ} \mathrm{C}$ or $100.4^{\circ} \mathrm{F}$ are considered as having a fever. Therefore, this person should not be allowed inside the premises of the business and ideally the person should be encouraged to seek medical attention [6].

\subsection{Personal protective equipment}

The use of PPE should be mandatory and provided, ideally by the employer to all employees. While in the premises of the establishment, the employee should be required to wear at least a mask, and if deemed necessary, gloves and hair bonnets (or caps) should be used, too. The masks and gloves should be changed periodically in order to eliminate cross contamination. The use of physical face barriers like goggles, face-shields should be mandatory considering air droplets could stay suspended in air. According to a recent study, when people wear masks, they avoid touching their faces unintentionally [7], and therefore, the presence of the mask will reduce the risk of touching your mouth with contaminated fingers. The use of some working gear (or clothing items that never leave the workplace) or even gowns could also be appropriate measures during this pandemic.

\subsection{Hand sanitizers}

The benefits of alcohol-based hand sanitizer dispensers mounted on the wall throughout a building is considered crucial in the fight against the spread of COVID-19. Hand sanitization could be beneficial for customers and employees since by its use, the virus could potentially be killed and thus eliminating cross-contaminating surfaces and items.

The World Health Organization (WHO) advised the placement of hand sanitizer dispensers in prominent places around the workplace and refilling of these devices on a regular basis [8]. This process is both easy and cost-effective. Vessley et al. (2007) determined that use of alcohol-based hand sanitizers is an alternative to hand washing [9].

\subsection{Floor stickers}

Social distancing (or the minimal distance between individuals in public places) is another important precaution for the prevention of COVID-19. Digitally printed circular or foot shaped floor stickers may be a useful guide for people to maintain social distance. These stickers can be placed on the floor to mark the space between each customer (say, while standing on the line at the cashier). Some store outlets around the globe even took the extra step to place arrows on the floor to indicate the direction in which customers should follow while shopping, therefore controlling the flow and movement inside the store. It is advised by the Center for Disease Control and Prevention (CDC) [6] that people should be at least two meters (approximately 40 inches $=$ six feet) apart in order to keep the social distancing and prevent COVID19 contamination [10]. Thus, the stickers can be organized to maintain this critical distance between individuals. 




Fig. 1. Plan view of the workplace without protection (the open areas are prone to contamination).

\subsection{Posters}

Posters promoting preventive measurements should be placed on walls throughout workplaces. The text on the posters should be brief, easy to understand, and the lettering and font size should be clear to read and seen from a distance. The text of the posters should promote frequent hand washing, avoiding touching one's face, coughing and sneezing into a tissue or even the bend of the arm should be encouraged [11]. In regions in which more than one language is spoken, such as in Quebec or California, such posters should be written in the appropriate

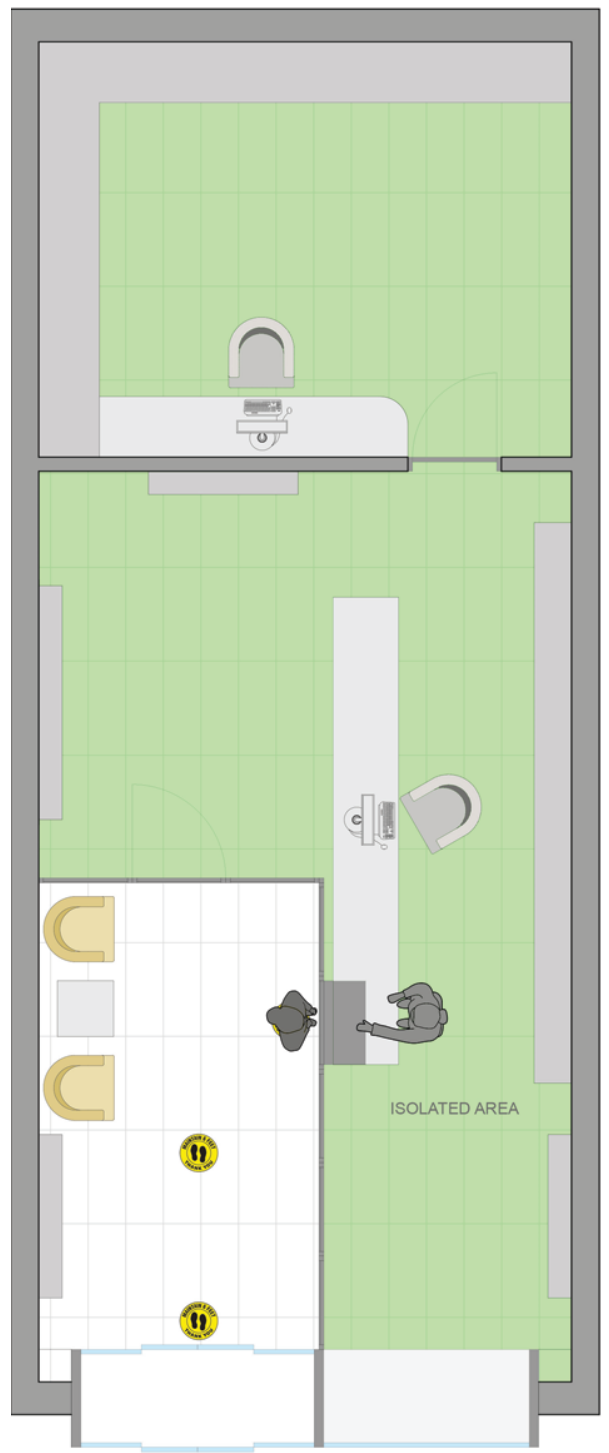

Fig. 2. Plan view of the workplace with PPMA shields' protection (the green areas have been protected against contamination).

local language(s). Also, in places with low- literacy rates, images showing the recommended prevented measure should be encouraged.

\subsection{Polymethyl methacrylate (PMMA) barriers}

Another tool that can be easily installed at a relatively low-cost is a barrier made of Polymethyl methacrylate (PMMA) or basically a clear hard plastic. The most common trademarks are Plexiglas, Astarglas, Crylux, Acrylite, Lucite, Perclax and Perspex. PMMA sheets are easy to work with as they are usually 4-5 millimeters in thickness, and these 


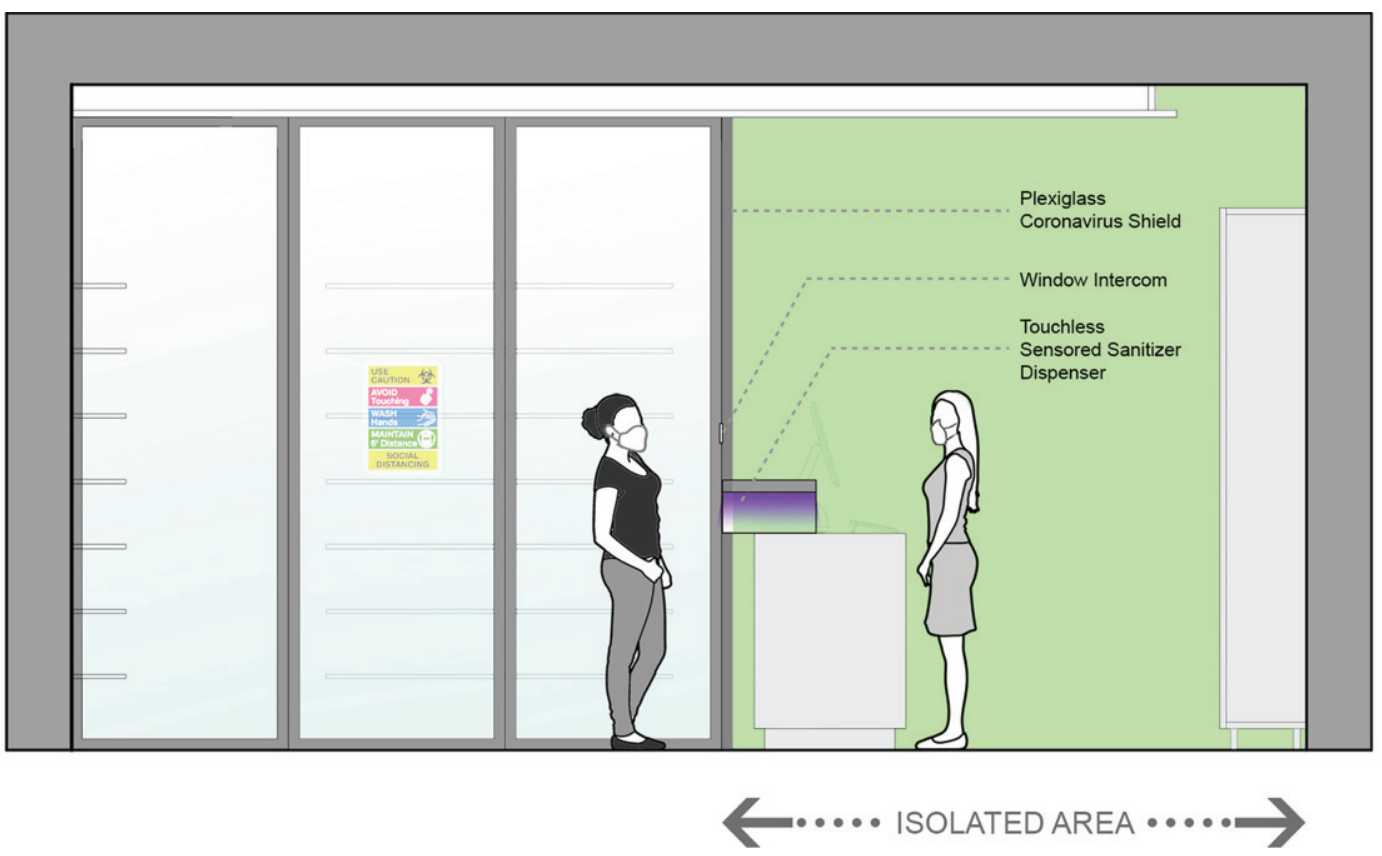

Fig. 3. Section view of the workplace with PPMA shields' protection (the green areas have been protected against contamination).

sheets can be shaped according to the needs of the user [12].

A barrier made of PMMA can be installed in the needed area to separate customers and employees (and even employees who might work side-by-side, say, at a chicken processing plant). This barrier can possibility minimize contamination among people in the same space. It is recommended that the PMMA barrier should be fixed from the ceiling all the way to the floor in order to be more effective.

\subsection{Rotating plate}

Nowadays, it has become common place to pay for things with a smartphone. For instance in China, one can easily use an applicative (e.g. Ali Pay app) installed in a smartphone to simply scan a barcode to conduct a transaction. In the United States and Canada, some people opt for using Apple Pay. That being said, in several other places, hard currency is still the norm, and therefore, other concepts must be introduced in order to conduct a traditional cash transaction.

A possible novel concept is introduced in this paper called the rotating plate, which basically is an area designed for payment between the cashier and the customer. This is a PMMA-made rotating plate which would be placed in a slot/terminal in the middle of the transparent plastic barrier. Through this device, money, coins and other forms of physical payment can be safely exchanged. One key safety element of the rotating plate is the motion sensors which will automatically stray disinfectant onto the content in the intermediate area. The rotating plate could be beneficial in banks/currency exchanger outlets, convenience stores, as well as drugstores. (Figures 1-5). These precautions (Table 2) can be easily implemented at different workplaces since these are fast, practical and cost-effective.

\section{Discussion}

During COVID-19, essential workers, as indicated earlier, could easily become vectors and spread the virus throughout the workplace and beyond. The more protected these workplaces become, the less likely COVID-19 will spread all over the world $[13,14]$.

To some extent, employers should be obliged to provide the means to ensure the well-being of their workforce $[15,16]$.

Another key aspect is to predict how individuals will behave in the workplace. For instance, valid questions can be raised to the extent in which employees are following the internal safety guidelines, and 
the use of PPE or even handwashing. Being able to predict how individual behave, will be crucial to contain COVID-19 [11]. The measures listed here should be taken by employers, in order to reduce the risk to employees [6].

The ventilation system is crucial considering that COVID-19 virus might be able to stay suspended in the air. That being said, it may be almost impossible

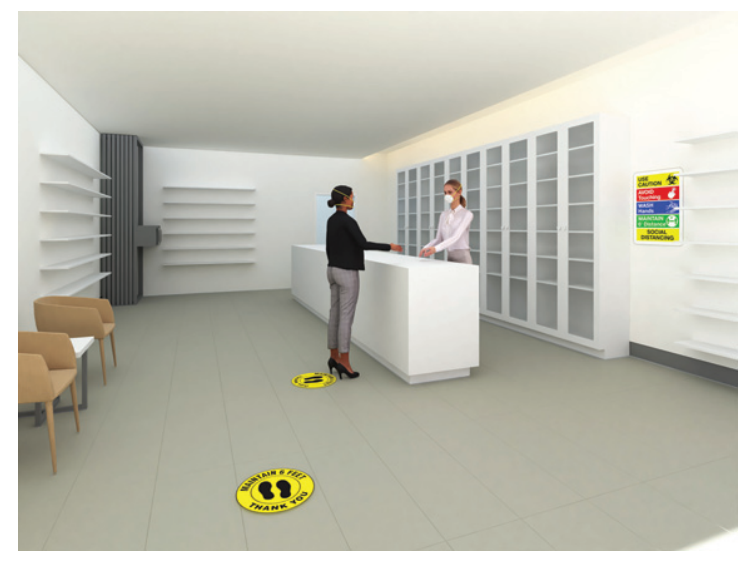

Fig. 4. Before the application of PMMA shields.

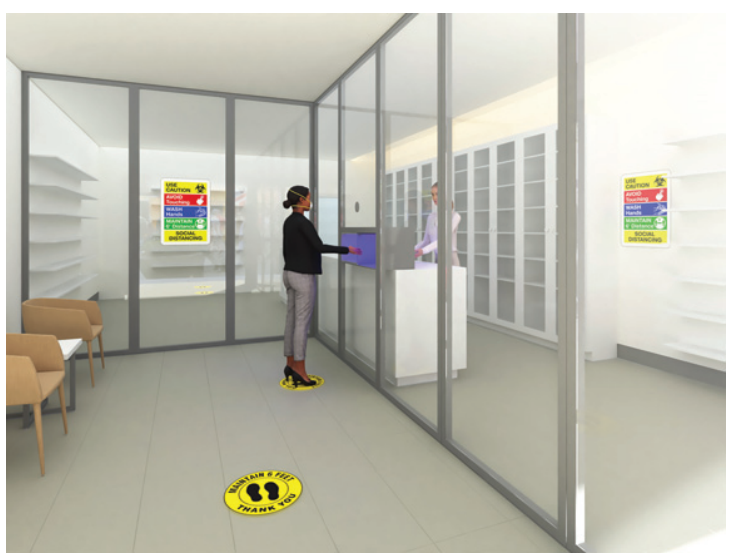

Fig. 5. After the application of PMMA shields. The rotating plate included a sanitizer (posters and floor stickers have been applied). to change existing ventilation system considering that any type of construction would be inconvenient and costly especially now that the pandemic is having a significant effect on the bottom line. Alternately, the use of ionizers may be beneficial, and they may be a powerful weapon as they are commonly used in the fight against hospital-acquired infection. Although two papers suggested that more research on the use of ionizers is needed, they could play a key role in the fight against COVID-19 [17, 18]. Although, a simple and economical approach would be to open windows and doors to let air circulate, in some buildings glass panels cannot be opened. Increasing the ventilation rates by opening windows may reduce the COVID-19 particles in the air [19].

Considering that construction and extensive redesign of spaces might be impractical due to time and cost. One viable alternative could be reducing the amount of personnel or employees present at work at the same time. In some companies like Facebook and Oracle, employees are allowed to work remotely. Since this might not be practical for some industries, it still would be a good idea to have different work shifts in order to reduce the amount of employees concentrated in the same area.

\section{Conclusion}

A large number of workers still need to work during the pandemic. Workspaces should be re-designed to implement necessary preventive measures in an expedite way. These precautions should be considered when employers create action plans for this current pandemic or any future calamities [20].

Some practical and cost-efficient ideas are introduced in this paper. Employers in both developed and developing countries may be forced to re-design the workplace in order to reduce the infection risk. The action of businesses, through the implementation of steps suggested here, maybe become one of the keys in the fight against COVID-19.

Table 2

A list of interior architectural preventive precautions for workplaces

\begin{tabular}{ll}
\hline Precautions & Usage \\
\hline Monitoring and recording the temperature & Using a digital wireless thermometer at the entrance of the workplace. \\
PPE & Masks, gloves, face-shields, work clothes. \\
Hand sanitizers & Mounted in the workplaces and refilled regularly. \\
Floor stickers & Keeping social and safe distance for the customers. \\
Posters & Preventive announcements for hygiene. \\
Transparent physical barriers & PMMA sheets to reduce human contact/interaction. \\
Transparent rotating plate & PMMA plates to reduce human contact/interaction in money/coin/credit card exchange. \\
\hline
\end{tabular}




\section{Acknowledgments}

The author would like to express his appreciation to all health workers, essential workplace employees, and frontline staff working every day during the COVID-19 pandemic all around the world.

\section{Conflict of interest}

The author declares no conflict of interest.

\section{Funding}

The author does not have any financial interest in the companies whose trade names are included in this article.

\section{References}

[1] World Health Organization. Coronavirus disease (COVID19) information. https://www.who.int/emergencies/disea ses/novel-coronavirus-2019 (last assessed 16 April 2020).

[2] Le Corbusier. "Eyes which do not see-Liners," in Toward an architecture, trans. John Goodman. London: Architectural Press, 1946, 85-103.

[3] Baker MG, Peckham TK, Seixas NS. Estimating the burden of United States workers exposed to infection or disease: a key factor in containing risk of COVID-19 infection. medRxiv. 2020. Preprint https://doi.org/10.1101/2020. 03.02.20030288 (Last accessed 16 April 2020).

[4] Chin A, Chu J, Perera M, Hui K, Yen HL, Chan M, Peiris M, Poon L. Stability of SARS-CoV-2 in different environmental conditions. medRxiv. 2020 Jan 1.

[5] Lee VJ, Chiew CJ, Khong WX. Interrupting transmission of COVID-19: lessons from containment efforts in Singapore. Journal of Travel Medicine. 2020 Mar 13.

[6] Center for Disease Control and Prevention, Coronovirus Disease 2019, Social Distancing. https://www.cdc.gov/ coronavirus/2019-ncov/prevent-getting-sick/socialdistancing.html (Last accessed 22 April 2020).

[7] Semple S, Cherrie JW. Covid-19: Protecting Worker Health. Annals of Work Exposures and Health. 2020 Mar 23;1:4.
[8] World Health Organization. Getting your workplace ready for COVID-19: How COVID-19 spreads, 19 March 2020. World Health Organization; 2020 Mar 19.

[9] Vessey JA, Sherwod JJ, Warner D, Clark D. Comparing Hand Washing to Hand Sanitizers in Reducing Elementary School Student's Absenteeism. Pediatric Nursing. 2007 Jul $1 ; 33(4)$

[10] Greenstone M, Nigam V. Does Social Distancing Matter? University of Chicago, Becker Friedman Institute for Economics Working Paper. 2020 Mar 25(2020-26).

[11] George R, George A. Prevention of COVID-19 in the workplace. SAMJ: South African Medical Journal. 2020;110(4): 269-70.

[12] Platt DK. Engineering and High Performance Plastics Market Report: A Rapra Market Report. Smithers Rapra. p. 170. ISBN 978-1-85957-380-8. 2003.

[13] Kowalski WJ, Walsh, TJ, Petraitis V. 2020 COVID-19 Coronavirus Ultraviolet Susceptibility. 2020. doi: 10.13140/ RG.2.2.22803.22566. (Last accessed 22 April 2020).

[14] Kurgat EK, Sexton JD, Garavito F, Reynolds A, Contreras RD, Gerba CP, Leslie RA, Edmonds-Wilson SL, Reynolds KA. Impact of a hygiene intervention on virus spread in an office building. International Journal of Hygiene and Environmental Health. 2019;222(3):479-85.

[15] Christian MS, Bradley JC, Wallace JC, Burke MJ. Workplace safety: a meta-analysis of the roles of person and situation factors. Journal of Applied Psychology. 2009;94(5): 1103.

[16] Maxwell W. Critical incident in workplace: safety, functional and administrative issues. Crisis, Stress and Human Resilience: An International Journal. Vol. I, No. 4 March 2020.

[17] Russell G. Coronavirus: Ionisers may be key in fight to defeat Covid-19. https://www.thenational.scot/news/ 18351414.coronavirus-ionisers-may-key-fight-defeatcovid-19/ (Last accessed 22 April 2020).

[18] Haiken M. Used in large-scale ventilation systems worldwide, bipolar ionization could be a secret weapon in the war against COVID-19. https://www.businessinsider. com/bipolar-ionization-could-be-a-secret-weapon-againstcovid-19-2020-4 (Last accessed 22 April 2020).

[19] Dalton C, Corbett S, Katelaris A. Pre-emptive low cost social distancing and enhanced hygiene implemented before local COVID-19 transmission could decrease the number and severity of cases. The Medical Journal of Australia. 2020;212(10):1.

[20] Fong MW, Gao H, Wong JY, Xiao J, Shiu EYC, Ryu S, et al. Nonpharmaceutical measures for pandemic influenza in nonhealthcare settings-social distancing measures. Emerg Infect Dis. 2020 May. https://doi.org/10.3201/eid2605. 190995 